\title{
ANALISIS ASPEK SOSIAL EKONOMI PETANI PADI PESERTA PROGRAM PENCETAKAN SAWAH BARU
}

\author{
Nurhana*, Rusli M. Rukka, Pipi Diansari, \\ Didi Rukmana, Sitti Bulkis, Rasyidah Bakri \\ Program Studi Agribisnis, Departemen Sosial Ekonomi Pertanian, \\ Fakultas Pertanian, Universitas Hasanuddin, Makassar \\ ${ }^{*}$ Kontak penulis: anhanurhana01@gmail.com
}

\begin{abstract}
The strategy to increase rice production to support national food security is realized through a rice field construction program. The rice field construction program aims to increase the area of rice fields through the expansion of rice fields. This study aims to: 1) Describe the farming profile before and after the rice field construction program in Botto Village, Pitu Riase District, Sidrap Regency, 2) Analyze changes in socio-economic aspects of participating farmers before and after the rice field construction program in Village Botto, Pitu Riase District, Sidrap Regency. The population of the study were all farmers who participated in the Rice Field Construction Program, which were 51 people using the entire population census method to become respondents. The analytical method used is quantitative descriptive analysis. The results of the study concluded that: 1) The rice field construction program in Botto Village, Pitu Riase Subdistrict, Sidrap Regency changed the farming profile in terms of non-productive land area and used, function and land use, cultivated species, ownership status and land tax. Utilization of human resources, equipment resources, financial resources and conditions of supporting facilities, 2) The rice field construction program provides socioeconomic changes to the communities in Botto Village in the form of labor use, increased interaction among farmers, changes in livelihood status and increased income.
\end{abstract}

Keywords: Rice Field Construction ; Farm Profile; Socio-Economic Change.

\begin{abstract}
ABSTRAK
Strategi peningkatan produksi padi untuk mendukung ketahanan pangan nasional, diwujudkan melalui program pencetakan sawah baru. Program pencetakan sawah baru bertujuan untuk menambah luas lahan sawah melalui kegiatan perluasan sawah. Penelitian ini bertujuan untuk: 1) Mendeskripsikan profil usahatani sebelum dan sesudah adanya program pencetakan sawah baru di Desa Botto, Kecamatan Pitu Riase, Kabupaten Sidrap, 2) Menganalisis perubahan aspek sosial ekonomi dari petani peserta sebelum dan sesudah adanya program pencetakan sawah baru di Desa Botto, Kecamatan Pitu Riase, Kabupaten Sidrap. Populasi dari penelitian adalah semua petani yang ikut dalam Program Pencetakan Sawah Baru yaitu sebanyak 51 orang dengan menggunakan metode sensus seluruh populasi menjadi responden. Metode analisis yang digunakan adalah analisis deskriptif kuantitatif. Hasil penelitian menyimpulkan bahwa: 1) Program pencetakan sawah baru di Desa Botto, Kecamatan Pitu Riase, Kabupaten Sidrap mengubah profil usahatani dalam hal luas lahan non produktif dan yang dimanfaatkan, fungsi dan pemanfaatan lahan, jenis tanaman yang dibudidayakan, status kepemilikan dan pajak lahan. Pemanfaatan sumber daya manusia, sumber daya peralatan, sumber daya finansial dan kondisi sarana penunjang, 2) Program pencetakan sawah baru memberikan perubahan sosial ekonomi kepada masyarakat di Desa Botto berupa penggunaan tenaga kerja, peningkatan interaksi sesama petani, perubahan status mata pencaharian dan peningkatan pendapatan.
\end{abstract}

Kata Kunci: Pencetakan Sawah Baru; Profil Usahatani; Perubahan Sosial Ekonomi. 
Sitasi: Nurhana*, Rusli M. Rukka, Pipi Diansari, Didi Rukmana, Sitti Bulkis, Rasyidah Bakri, 2019. Analisis Aspek Sosial Ekonomi Petani Padi Peserta Program Pencetakan Sawah Baru, ISEP 15(1): 17 - 30.

Indonesia saat ini dihadapkan pada permasalahan ketahanan pangan. Hal ini dikarenakan terjadinya ketidakseimbangan antara peningkatan populasi penduduk dengan perluasan lahan pertanian. Lahan produktif yang seharusnya digunakan sebagai lahan pertanian telah banyak dikonversi menjadi lahan non pertanian guna memenuhi kebutuhan pemukiman penduduk. Disisi lain, kebutuhan pangan yang meningkat tajam belum mampu ditanggulangi oleh produksi pertanian lokal sehingga pemerintah harus melakukan impor pangan dari luar negeri.

Berdasarkan data BPS (2016) tingkat impor beras Indonesia pada tahun 2015 mencapai 861.630 ton. Angka impor yang cukup tinggi bagi negara yang dijuluki sebagai negara agraris. Permasalahan lain yang tak kalah pentingnya yaitu semakin menurunnya luas pemillikan lahan oleh petani karena alih fungsi lahan pertanian ke lahan pemukiman ataupun perindustrian yang tidak dibarengi dengan perluasan lahan sawah yang seimbang. Adanya alih fungsi lahan pertanian menjadi non pertanian, tentu akan menyebabkan penurunan produksi pertanian termasuk menurunnya produksi beras. Salah satu upaya untuk mencegah terjadinya penurunan produksi hasil pertanian dan untuk memenuhi kebutuhan pangan adalah melalui ekstensifikasi.

Dengan bertambahnya penduduk, perluasan lahan tanah pertanian untuk masa depan sangatlah penting. Akan tetapi, usaha untuk memperbaiki tanah yang sedang dipergunakan sekarang jangan diabaikan, karena perluasan lahan tanah pertanian cenderung memberikan dampak dalam jangka panjang. Alasan utama membenarkan pembukaan lahan tanah pertanian baru ialah bahwa pembukaan tanah ini akan memperkokoh pertanian dalam jangka panjang (Mosher dalam kurniawan, 2017).

Kabupaten Sidrap adalah salah satu kabupaten yang berada di Provinsi Sulawesi Selatan yang dijuluki lumbung padi. Sidrap memiliki luas wilayah 2.506,19 $\mathrm{km}^{2}$ dan berpenduduk sebanyak kurang lebih 264.955 jiwa. Sidrap memilki lahan sawah seluas $47.947,3$ ha dan mampu melaksanakan panen hingga tiga kali setahun dengan pelaksanaan program percepatan tanam. Dengan potensi pertanian yang dimiliki Kabupaten Sidrap maka untuk mempertahankan dan meningkatkan produksi padi, Kabupaten Sidrap menjadi salah satu kabupaten yang menerima program pencetakan sawah baru yang dilakukan oleh Kementrian Pertanian.

Desa Botto terdapat gambaran sosial yang menarik untuk di amati. Berdasarkan hasil survey diperoleh informasi dari Penyuluh Pertanian Lapangan (PPL) bahwa banyak petani yang membuka lahan tidur untuk dijadikan sawah baru melalui program pencetakan sawah baru yang diadakan oleh pemerintah. Lahan yang dijadikan sawah baru yaitu lahan alang-alang dan lahan perkebunan, akan tetapi mayoritas yang dijadikan sawah baru adalah lahan alang-alang. Melalui program pencetakan sawah baru, sejumlah lahan tidur dapat didayagunakan sehingga program ini sejalan dengan upaya untuk mendukung penyediaan pangan oleh pemerintah. 
Tabel 1.

Nama Kecamatan, Desa/Kelurahan, Luas lahan, di Kabupaten Sidrap, 2018.

\begin{tabular}{|c|c|c|c|c|}
\hline No. & Kecamatan & Desa/Kelurahan & $\begin{array}{c}\text { Luas Lahan Cetak } \\
\text { Sawah Baru (ha) }\end{array}$ & $\%$ \\
\hline 1. & Watang Sidenreng & Talawe & 11,00 & 5,00 \\
\hline 2. & Watang Sidenreng & Damai & 8,00 & 3,64 \\
\hline 3. & Kulo & Rijang Panua & 25,00 & 11,36 \\
\hline 4. & Kulo & Maddenra & 37,00 & 16,82 \\
\hline 5. & Pitu Riawa & Bulu Cenrana & 10,00 & 4,55 \\
\hline 6. & Pitu Riawa & Betao Riawa & 29,00 & 13,18 \\
\hline 7. & Pitu Riawa & Betao Riase & 14,00 & 6,36 \\
\hline 8. & Pitu Riase & Botto & 63,90 & 29,04 \\
\hline 9. & Pitu Riase & Batu & 13,70 & 6,23 \\
\hline 10. & Pitu Riase & Bila Riase & 8,40 & 3,82 \\
\hline \multicolumn{3}{|c|}{ Total } & 220,00 & 100,00 \\
\hline
\end{tabular}

Sumber: Dinas Pertanian Sidrap, 2018.

Sebelum adanya program pencetakan sawah baru, masyarakat di Desa Botto mayoritas berprofesi sebagai petani padi baik itu sebagai petani penggarap ataupun petani pemilik. Akan tetapi, ada beberapa petani yang memiliki pekerjaan sampingan sebagai petani jagung. Selain mempunyai lahan untuk tanaman jagung petani tersebut juga memiliki lahan tidur yang ditumbuhi rerumputan yang tidak memiliki nilai ekonomi, kemudian lahan tidur inilah yang mereka buka dan dijadikan sebagai sawah baru.

Pada umumnya kondisi lahan sawah baru hasil program pencetakan sawah baru belum terbentuk lapisan kedap air, sehingga perubahan sifat-sifat tanah dapat mengganggu pertumbuhan tanaman. Oleh karena itu, penting bagi petani untuk mengontrol kondisi pengairan sawahnya dan mengontrol keberadaan gulma dan pengganggu lainnya. Selain itu, beberapa bagian konstruksi pada sawah baru belum kokoh, seperti pematang atau batas-batas sawah, saluran dan bangunan-bangunan irigasi. Maka dari itu, petani perlu merawat dan menjaganya supaya proses pelaksanaan usahatani di lahan sawah baru dapat berjalan lancar sesuai yang diharapkan.

Berdasarkan prasurvey yang dilaksanakan di Desa Botto hasil panen perdana masih belum maksimal jika dibandingkan dengan sawah lama, hal ini dikarenakan sawah baru hasil program pencetakan masih dalam tahap pemantapan dari keseluruhan fasilitas seperti irigasi, unsur hara yang belum stabil dan penyesuaian PH tanah pada sawah baru hasil program pencetakan sawah baru.

Program pencetakan sawah baru diharapkan dapat memengaruhi kehidupan sosial ekonomi masyarakat menjadi lebih baik dibanding sebelum adanya program tersebut. Melalui program ini diharapkan terjadi peningkatan taraf hidup masyarakat, melalui penyerapan tenaga kerja yang kemudian memberikan pekerjaan baru bagi masyarakat, pemanfaatan lahan dan peningkatan pendapatan petani melalui hasil produksi dalam usahatani yang dilakukan di sawah baru hasil program pencetakan sawah baru.

Berdasarkan latar belakang di atas tujuan dari penelitian ini adalah mendeskripsikan profil usahatani sebelum dan sesudah adanya program pencetakan sawah baru di Desa Botto, Kecamatan Pitu Riase, Kabupaten Sidrap dan menganalisis perubahan aspek sosial ekonomi dari petani peserta sebelum dan 
sesudah adanya program pencetakan sawah baru di Desa Botto, Kecamatan Pitu Riase, Kabupaten Sidrap.

\section{Metoda Penelitian}

Penelitian ini dilaksanakan di Desa Botto, Kecamatan Pitu Riase, Kabupaten Sidrap, Provinsi Sulawesi Selatan. Pemilihan lokasi dilakukan secara purposive (sengaja) dengan pertimbangan bahwa lokasi tersebut merupakan salah satu daerah penerima program pencetakan sawah baru dengan lahan terluas (63,90 Ha). Jenis data yang digunakan dalam penelitian ini terdiri dari data primer dan data sekunder. Dalam penelitian ini data primer diperoleh dari hasil wawancara langsung dengan responden yang tergabung dalam tiga kelompok tani yang ada di Desa Botto, Kecamatan Pitu Riase menggunakan kuesioner. Sedangkan data sekunder diperoleh di instansi atau lembaga setempat seperti dari Kantor Desa Botto, Kantor Kecamatan Pitu Riase, Dinas Pertanian Kabupaten Sidrap dan BPS (Badan Pusat Statistik).

Populasi dari penelitian adalah semua petani yang ikut dalam Program Pencetakan Sawah Baru yaitu sebanyak 51 orang dengan menggunakan metode sensus. Sensus adalah teknik penentuan sampel bila semua anggota populasi digunakan sebagai sampel (Sugiyono, 2008). Metode analisis yang digunakan adalah analisis deskriptif kuantitatif.

Untuk mendeskripsikan profil usahatani sebelum dan sesudah adanya program pencetakan sawah analisis yang digunakan adalah analisis deskriptif. Menurut Whitney (dalam Kurniawan, 2017) metode deskriptif adalah pencarian fakta dengan interpretasi yang tepat. Tujuan dari penelitian deskriptif ini adalah untuk membuat deskripsi, gambaran atau lukisan secara sistematis, faktual dan akurat mengenai fakta-fakta, sifat-sifat serta hubungan antar fenomena yang diselidiki mengenai pelaksanaan program pencetakan sawah baru.

Untuk menganalisis perubahan aspek sosial ekonomi dari petani peserta sebelum dan sesudah adanya program pencetakan sawah baru maka dianalisis secara deskriptif kuantitatif. Untuk mengetahui aspek sosial maka dianalisis secara deskriptif dengan melihat variabel penyerapan tenaga kerja, interaksi sosial, mata pencaharian, sedangkan aspek ekonomi program pencetakan sawah baru dianalisis secara deskriptif kuantitatif dengan melihat variabel pendapatan.

Menurut Soekartawi (dalam Kurniawan, 2017), untuk mengetahui seberapa besar pendapatan (keuntungan) usahatani yang diperoleh sawah baru hasil program pencetakan sawah dapat dihitung menggunakan rumus sebagai berikut:

Pendapatan : $\mathrm{I}=\mathrm{TR}-\mathrm{TC}$

$$
\begin{aligned}
\text { Keterangan }: & \mathrm{I} \quad=\text { Pendapatan (Income), } \\
\mathrm{TR} & =\text { Total Penerimaan } \\
\mathrm{TC} & =\text { Total Biaya }
\end{aligned}
$$

Biaya $:$ TC $=$ TFC + TVC

$$
\text { Keterangan: } \begin{aligned}
\mathrm{TC} & =\text { Total Biaya }(\mathrm{Rp}) \\
\mathrm{TFC} & =\text { Total Biaya Tetap }(\mathrm{Rp}) \\
\mathrm{TVC} & =\text { Total Biaya Variabel }(\mathrm{Rp})
\end{aligned}
$$




$$
\begin{aligned}
\text { Penerimaan }: \text { TR }=\mathbf{P} \cdot \mathbf{Q} \\
\text { Keterangan : TR } \quad=\text { Total Penerimaan }(\mathrm{Rp}) \\
\mathrm{P} \quad=\text { Harga }(\mathrm{Rp} / \mathrm{Kg}) \\
\mathrm{Q} \quad=\text { Produksi }(\mathrm{Kg})
\end{aligned}
$$

\section{Hasil dan Pembahasan}

Kegiatan pencetakan sawah baru di Desa Botto diarahkan pada lahan irigasi. Pencetakan sawah pada lahan irigasi merupakan upaya menambah luas lahan sawah yang dilakukan di daerah irigasi yang belum dimanfaatkan dan mempunyai sumber air yang cukup untuk pertumbuhan tanaman padi. Jumlah luasan sawah baru yang terealisasi seluas 63,90 Ha yang penyebarannya terdiri dari tiga kelompok tani. Luas lahan Kelompok Tani Sipakaenre yaitu 25,50 Ha, Kelompok Tani Sipurennu 22,20 Ha dan Kelompok Tani Abadi seluas 16,20 Ha.

Petani yang mendapatkan program, 66,67\% diantaranya berumur produktif yaitu 42-54 tahun yang sebagian besar pendidikannya SMP/Sederajat dengan jumlah 23 orang. Petani memiliki pengalaman yang cukup lama dalam berusahatani padi sawah. Hal ini terbukti dari hasil penelitian yang memperlihatkan bahwa sekitar 58,82\% petani memiliki pengalaman 18-29 tahun dalam berusahatani.

\section{Profil Usahatani Sebelum dan Sesudah Adanya Program Pencetakan Sawah Baru}

\section{a. Luas Lahan Non Produktif}

Lahan non produktif merupakan sebuah areal pertanian yang dibiarkan tanpa adanya usaha pemanfaatan di lahan tersebut. Adapun luas lahan non produktif yang dimiliki petani responden di Desa Botto dapat dilihat pada Tabel 2.

Tabel 2.

Luas Lahan Non Produktif dan Termanfaatkan yang dimiliki Petani Responden

Sebelum dan Sesudah Adanya Program di Desa Botto, Kecamatan Pitu Riase, Kabupaten Sidrap, 2018.

\begin{tabular}{ccrrrr}
\hline \multirow{2}{*}{ No. } & Jenis Lahan & \multicolumn{2}{c}{ Sebelum } & \multicolumn{2}{c}{ Sesudah } \\
\cline { 3 - 6 } & \multicolumn{2}{c}{$\begin{array}{c}\text { Luas Lahan } \\
\text { (ha) }\end{array}$} & \multicolumn{1}{c}{$\%$} & $\begin{array}{c}\text { Luas Lahan } \\
\text { (ha) }\end{array}$ & \multicolumn{1}{c}{$\%$} \\
\hline 1 & Lahan Non Produktif & 97,45 & 88,19 & 46,60 & 42.17 \\
2 & Lahan yang dimanfaatkan & 13,05 & 11,81 & 63,90 & 57.83 \\
\hline \multicolumn{2}{c}{ Jumlah } & $\mathbf{1 1 0 , 5 0}$ & $\mathbf{1 0 0 , 0 0}$ & $\mathbf{1 1 0 , 5 0}$ & $\mathbf{1 0 0 , 0 0}$ \\
\hline
\end{tabular}

Tabel 2 menunjukkan lahan non produktif sebelum dan sesudah ada program mengalami penurunan. Hal ini disebabkan karena banyak lahan yang termanfaatkan sesudah ada program. Selain itu, lahan yang termanfaatkan sebelum dan sesudah ada program mengalami peningkatan dikarenakan dengan adanya program pencetakan sawah baru sejumlah lahan non produktif banyak dijadikan sebagai sawah baru.

b. Fungsi Lahan, Pemanfaatan Lahan dan Jenis Tanaman

Fungsi lahan sebelum dan Sesudah adanya program pencetakan sawah baru 
dapat dilihat pada Tabel 3.

Tabel 3.

Luas Lahan Berdasarkan Fungsinya Sebelum dan Sesudah Adanya Program Pencetakan Sawah Baru di Desa Botto, Kecamatan Pitu Riase, Kabupaten Sidrap, 2018

\begin{tabular}{|c|c|c|c|c|c|}
\hline \multirow[b]{2}{*}{ No. } & \multirow[b]{2}{*}{ Fungsi Lahan } & \multicolumn{2}{|c|}{ Sebelum } & \multicolumn{2}{|c|}{ Sesudah } \\
\hline & & $\begin{array}{l}\text { Luas Lahan } \\
\text { (Ha) }\end{array}$ & $\begin{array}{c}\text { Jumlah } \\
\text { Responden }\end{array}$ & $\begin{array}{l}\text { Luas Lahan } \\
\text { (Ha) }\end{array}$ & $\begin{array}{c}\text { Jumlah } \\
\text { Responden }\end{array}$ \\
\hline 1 & Lahan Tidur & 50,85 & 39 & 0 & 0 \\
\hline 2 & Kebun & 13,05 & 12 & 0 & 0 \\
\hline 3 & Sawah & - & 0 & 63,90 & 51 \\
\hline & Jumlah & 63,90 & 51 & 63.90 & 51 \\
\hline
\end{tabular}

Tabel 3 menunjukkan fungsi lahan sebelum dan sesudah adanya program adalah lahan tidur dan kebun, akan tetapi setelah adanya program lahan tersebut beralih menjadi sawah. Responden yang memiliki lahan kebun tidak mengambil hasil dari kebun tersebut sehingga responden memilih membuka sawah baru dari lahan kebun tersebut.

c. Luas Lahan Sawah Baru yang dimiliki Petani Responden

Luas lahan sawah baru sebelum dan Sesudah adanya program pencetakan sawah baru dapat dilihat pada Tabel 4 .

Tabel 4

Jumlah Responden Berdasarkan Luas Lahan Sawah Baru yang dimiliki Petani Responden Sebelum dan Sesudah Adanya Program Pencetakan Sawah Baru di Desa Botto, Kecamatan Pitu Riase, Kabupaten Sidrap, 2018.

\begin{tabular}{ccccccr}
\hline \multirow{2}{*}{ No. } & Luas Lahan & \multicolumn{2}{c}{ Sebelum } & \multicolumn{3}{c}{ Sesudah } \\
\cline { 3 - 7 } & $\mathbf{( H a )}$ & Orang & $\mathbf{0}$ & Orang & $\mathbf{\%}$ \\
\hline 1 & $<1$ & 0 & 00,00 & 13 & 25,50 \\
2 & $1-1.50$ & 0 & 00,00 & 22 & 43,13 \\
3 & $>1.50$ & 0 & 00,00 & 16 & 31,37 \\
\hline & Jumlah & $\mathbf{0}$ & $\mathbf{0 0 , 0 0}$ & $\mathbf{5 1}$ & $\mathbf{1 0 0 , 0 0}$ \\
\hline
\end{tabular}

Tabel 4 menunjukkan sesudah adanya program pencetakan sawah baru, petani responden pada umumnya memiliki lahan yang cukup luas yakni 1-1.50 Ha. Lahan yang luas memberikan kesempatan petani untuk mengusahakan usahatani sebanyak-banyaknya, namun disisi lain lahan yang luas akan menyebabkan rendahnya produktivitas lahan jika petani tidak optimal dalam mengusahakan usahataninya.

\section{d. Status Kepemilikan Lahan dan Pajak Lahan}

Status kepemilikan lahan yang dimiliki petani responden umumnya milik pribadi. Selain itu, ajak yang dikeluarkan sebelum adanya program sebesar $\mathrm{Rp}$ 1.728.000,- dengan rata-rata $\mathrm{Rp} 66.461 .54,-$ dan sesudah adanya program sebesar $\mathrm{Rp}$ 2.911.500,- dengan rata-rata $\mathrm{Rp} 111.980 .77,-$. Berdasarkan keterangan responden pajak yang dikeluarkan sebelum adanya program adalah pajak lahan tidur sebesar 
Rp 25.000,-/Ha, pajak kebun sebesar Rp 35.000,-/Ha dan sesudah adanya program pajak yang dikeluarkan adalah pajak lahan sawah sebesar Rp. 100.000,-/Ha.

\section{Pelaksanaan Kegiatan Usahatani}

Berdasarkan Tabel 3 bahwa fungsi lahan sebelum adanya program pencetakan sawah baru adalah lahan tidur dan kebun. Lahan kebun yang dimiliki responden dipelihara oleh kerabatnya dan dibiarkan saja tanpa dipelihara oleh pemiliknya sehingga petani responden tidak melakukan kegiatan apa pun di lahan tersebut. Akan tetapi, sesudah adanya program pencetakan sawah baru petani responden melakukan kegiatan usahatani mulai dari pengolahan lahan sampai pascapanen.

\section{a. Pengolahan Lahan}

Pengolahan lahan pada musim tanam pertama dan musim tanam kedua menggunakan mesin traktor dikarenakan tidak ada lagi petani yang menggunakan hewan untuk membajak lahan. Selain menggunakan mesin trakor, petani juga menggunakan cangkul. Untuk petani yang tidak memiliki mesin traktor mereka menyewa traktor dengan biaya bervariasi sesuai dengan luas lahan, dimana semakin luas lahan yang ingin digarap maka semakin besar pula biaya sewa yang harus dikeluarkan. Di samping menghemat waktu, penggunaan traktor juga menghemat tenaga kerja sehingga dalam pengolahan lahan musim tanam pertama dan kedua menggunakan 1 orang petani untuk membajak serta meratakan kembali tanah yang telah ditraktor.

\section{b. Penanaman}

Penanaman dilakukan dengan menggunakan sistem tanam benih langsung (TABELA) dengan jarak tanam yang bervariasi sesuai kebutuhan petani. Ada tiga jenis benih yang digunakan petani responden yaitu benih varietas St Bagendi, Pongga dan Ciherang. Adapun bantuan benih yang diberikan oleh pemerintah dapat dilihat pada Tabel 5.

\section{Tabel 5.}

Jumlah dan Jenis Benih Bantuan yang diterima Kelompok Tani di Sawah baru Program Pencetakan Sawah Baru di Desa Botto, Kecamatan Pitu Riase, Kabupaten Sidrap, 2018.

\begin{tabular}{|c|c|c|c|c|}
\hline \multirow{2}{*}{ No. } & \multirow{2}{*}{$\begin{array}{c}\text { Nama Kelompok } \\
\text { Tani }\end{array}$} & \multirow{2}{*}{ Jenis benih } & \multicolumn{2}{|c|}{ Jumlah Rata-Rata } \\
\hline & & & $\mathrm{Kg}$ & $\%$ \\
\hline 1 & Sipakaenre & Situ Bagendi & 33,58 & 35,97 \\
\hline 2 & Sipurennu & Pongga & 30,83 & 33,03 \\
\hline 3 & Abadi & Situ Bagendi & 28,93 & 31,00 \\
\hline & & Jumlah & 93,34 & 100,00 \\
\hline
\end{tabular}

Kelompok Tani Sipakaenre memperoleh bantuan benih sebanyak $638 \mathrm{~kg}$. Kelompok Tani Sipurennu sebanyak $555 \mathrm{~kg}$ dan Kelompok Tani Abadi sebanyak 405 $\mathrm{kg}$. Berdasarkan keterangan responden, bantuan benih yang diberikan pemerintah masing-masing petani sebanyak $25 \mathrm{~kg} / \mathrm{Ha}$ satu kali musim tanam. Petani responden di Desa Botto melakukan penanaman pada musim tanam pertama dan kedua menggunakan alat tanam benih langsung yaitu paralong. Penggunaan alat tanam ini 
selain menghemat waktu juga menghemat tenaga kerja sehingga dalam tahap penanaman musim tanam pertama dan kedua biasanya menggunakan tenaga kerja 1 hingga 3 orang petani yang disesuaikan dengan luas lahan milik petani responden.

c. Pemupukan

Pupuk yang digunakan petani responden umumnya sama yakni pupuk kandang, urea, sp36, za dan ponska. Adapun pupuk bantuan yang diberikan oleh pemerintah dapat dilihat pada Tabel 6.

Tabel 6.

Jumlah dan Jenis Pupuk Bantuan yang diterima Kelompok Tani di Sawah baru Program Pencetakan Sawah Baru di Desa Botto, Kecamatan Pitu Riase, Kabupaten Sidrap, 2018.

\begin{tabular}{|c|c|c|c|c|c|c|c|}
\hline \multirow[b]{2}{*}{ No. } & \multirow[b]{2}{*}{$\begin{array}{c}\text { Nama } \\
\text { Kelompok Tani }\end{array}$} & \multicolumn{6}{|c|}{ Jumlah Rata-Rata Pupuk } \\
\hline & & Urea (Kg) & $\%$ & SP36 (Kg) & $\%$ & $\begin{array}{l}\text { Pembedah } \\
\text { Tanah (Ltr) }\end{array}$ & $\%$ \\
\hline 1 & Sipakaenre & 167,78 & 35,96 & 134,21 & 35,96 & 6,73 & 36,01 \\
\hline 2 & Sipurennu & 154,17 & 33,04 & 123,33 & 33,04 & 6,17 & 33,01 \\
\hline 3 & Abadi & 144,64 & 31,00 & 115,71 & 31,00 & 5,79 & 30,98 \\
\hline & Jumlah & 466,59 & 100,00 & 373,25 & 100,00 & 18,69 & 100,00 \\
\hline
\end{tabular}

Ada dua jenis pupuk bantuan yaitu urea dan SP36. Kelompok Tani Sipakaenre memperoleh pupuk urea sebanyak 3,188 kg, SP36 2,550 kg, Kelompok Tani Sipurennu, urea sebanyak 2,775 kg, SP36 2,220 kg dan Kelompok Tani Abadi, urea sebanyak 2,025 kg, SP36 1,620 kg. Selain pupuk urea dan SP36, petani responden juga menerima bantuan pembedah tanah semacam pupuk cair. Untuk Kelompok Tani Sipakaenre dengan jumlah 128 ltr, Kelompok Tani Sipurennu 111 ltr dan Kelompok Tani Abadi 81 ltr. Untuk pemupukan sendiri petani menggunakan ember sebagai wadah pupuk dan menggunakan tenaga kerja 1 hingga 2 orang petani dikarenakan tidak memerlukan banyak tenaga kerja.

\section{d. Pemeliharaan}

Pada proses pemeliharaan petani menggunakan pestisida yang berbeda sesuai kebutuhan petani. Adapun pestisida yang digunakan petani responden dapat dilihat pada Tabel 7.

Tabel 7.

Kelompok Tani, Jenis Pestisida yang digunakan Sesudah Adanya Program Pencetakan Sawah Baru di Desa Botto, Kecamatan Pitu Riase, Kabupaten Sidrap, 2018.

\begin{tabular}{ccccl}
\hline \multirow{2}{*}{ No. } & \multirow{2}{*}{$\begin{array}{c}\text { Nama Kelompok } \\
\text { Tani }\end{array}$} & \multicolumn{2}{c}{ Jumlah Anggota } & \multicolumn{1}{c}{ Jenis Pestisida } \\
\cline { 3 - 4 } 1 & Orang & \% & \\
\hline 2 & Sipakaenre & 19 & 37,25 & $\begin{array}{l}\text { Clipper, Basagram, Klensect, Regent } \\
\text { Cair, Amolin }\end{array}$ \\
3 & Abadi & 18 & 35,29 & $\begin{array}{l}\text { Basagram, Aripong, Clipper, Spontan, } \\
\text { DMA 6 } \\
\text { Regent Cair, Aripong, Basagram, } \\
\text { Clipper }\end{array}$ \\
\hline & Jumlah & 14 & 27,46 & \\
\hline
\end{tabular}


Berdasarkan keterangan responden, untuk pestisida tidak ada bantuan dari pemerintah, sehingga petani harus mengeluarkan biaya pribadi untuk membeli pestisida. Pada tahap pemeliharaan sendiri petani menggunakan sprayer untuk melakukan penyemprotan bertujuan untuk mengendalikan hama dan penyakit. Tahap penyemprotan menggunakan tenaga kerja 1 hingga 2 orang petani dikarenakan pengerjaannya tidak memerlukan banyak tenaga kerja.

\section{e. Panen dan Pascapanen}

Petani responden melakukan pemanenan menggunakan mesin combine. Tenaga kerja yang digunakan pada saat pemanenan musim tanam pertama dan kedua yaitu 7-9 orang dengan waktu pengerjaan \pm satu jam per hektare. Tenaga kerja yang digunakan ada yang bertugas sebagai operator dan karyawan. Untuk karyawan upah per orang sebesar Rp 7.000,- per karung dan untuk operator Rp 4.000,- per karung.

Gabah yang telah di panen selanjutnya diangkut dari sawah ke pinggir jalan. Pengangkutan dari sawah ke pinggir jalan dilakukan menggunakan motor. Pengangkutan dengan menggunakan motor akan dibayar dengan upah Rp 8,000,sampai Rp 10,000,- per karung gabah yang dibawa. Upah yang dibayarkan sesuai dengan kesepakatan antara petani dengan tenaga kerja pemilik motor dimana semakin jauh jarak sawah dari pinggir jalan maka upah yang dikeluarkan juga semakin besar, begitu pula sebaliknya.

\section{f. Sumber Modal}

Modal berperan penting dalam kegiatan usahatani, dalam kegiatan usahatani sederhana peran modal yang diperlukan kecil, namun semakin maju usahatani modal yang diperlukan semakin besar. Modal yang dikeluarkan petani responden dalam melakukan kegiatan usahatani sebelum dan sesudah adanya program dapat dilihat pada Tabel 8.

Tabel 8.

Modal Petani Responden Sebelum dan Sesudah Adanya Program Pencetakan Sawah Baru di Desa Botto, Kecamatan Pitu Riase, Kabupaten Sidrap, 2018.

\begin{tabular}{cccr}
\hline No. & Modal & $\begin{array}{c}\text { Sebelum } \\
(\mathbf{R p})\end{array}$ & \multicolumn{2}{c}{$\begin{array}{c}\text { Sesudah } \\
\mathbf{( R \mathbf { p } )}\end{array}$} \\
\hline 1 & Musim Tanam Pertama & 0 & $41,299,500$ \\
2 & Musim Tanam Kedua & 0 & $\mathbf{1 3 6 , 1 0 5 , 0 2 5}$ \\
\hline \multicolumn{2}{c}{ Jumlah } & $\mathbf{0}$ & $\mathbf{1 7 7 , 4 0 4 , 5 2 5}$ \\
\hline
\end{tabular}

Tabel 8 menunjukkan sebelum adanya program tidak ada modal yang dikeluarkan oleh petani responden. Hal ini dikarenakan sebelum adanya program lahan tersebut merupakan lahan tidur dan kebun yang tidak diusahakan oleh pemiliknya. Sesudah adanya program pencetakan sawah baru petani responden melakukan kegiatan usahatani di lahan tersebut sehingga petani mengeluarkan modal untuk membiayai kegiatan usahatani yang dilakukan di lahan sawah baru. 
a. Jalan

Lokasi lahan sawah baru hasil program pencetakan sawah baru berada di tiga lokasi yaitu Dusun Labekkang, Dusun Uloe, Dusun Botto. Akses menuju lokasi lahan sawah baru hasil program pencetakan sawah baru dapat dilakukan melalui jalan Dusun Toddang Asa (Dusun Labekkang), jalan Dusun Loka Lokae (Dusun Uloe) dan melalui jalan poros Dusun Botto (Dusun Botto). Kondisi jalan sebelum dan sesudah adanya program umumnya sama yaitu pengerasan. Berdasarkan keterangan petani responden jalan tersebut dapat dilewati kendaraan mobil dan motor.

Kondisi jalan menuju lokasi pertama kurang baik ketika musim hujan dan akan sulit dilewati menggunakan mobil. Hal tersebut dikarenakan kondisi jalan awalnya pengerasan tetapi kini sebagian besar sudah hancur. Lokasi sawah baru di Dusun Uloe dekat dari pemukiman warga. Sedangkan akses menuju lokasi ketiga (Dusun Botto) kondisi jalan lebih bagus dari kedua jalan sebelumnya. Jalan dusun Botto sudah dalam kondisi sebagian aspal dan sebagian pula pengerasan. Lokasi ketiga terletak dijalan poros Dusun Botto sehingga akses ke lokasi sawah baru tersebut mudah.

\section{b. Irigasi}

Irigasi yang ada di daerah lahan sawah baru hasil program pencetakan sawah baru merupakan irigasi non teknis. Hal ini dapat dilihat dari kondisi irigasi yang masih belum permanen dan masih berbentuk saluran sederhana. Selain itu kelengkapan maupun kemampuan dalam mengukur dan mengatur air masih sangat sederhana.

Irigasi di Dusun Labekkang adalah embung. Ketersediaan air di embung tersebut kurang sehingga pada musim tanam pertama lahan sawah baru tidak diusahatanikan. Irigasi di lokasi Dusun Uloe yaitu menggunakan bak penampung air. Kondisi bak penampungan air di Dusun Uloe belum jadi sehingga air yang digunakan petani responden dalam mengusahatanikan lahannya berasal dari air sungai.

Irigasi yang ada di lokasi Dusun Botto yaitu embung. Letak embung berada ditengah-tengah sawah baru hasil program pencetakan sawa baru. Ketersediaan air di embung tersebut selalu ada. Proses pengaliran air ke lahan sawah baru menggunakan pompa air.

\section{Aspek Sosial Ekonomi Sebelum dan Sesudah Adanya Program Pencetakan Sawah Baru}

Aspek Sosial

\section{a. Penggunaan Tenaga Kerja}

Berdasarkan Tabel 3 tidak ada aktivitas usahatani yang dilakukan dilahan sebelum adanya program. Akan tetapi, sesudah adanya program petani responden melakukan kegiatan usahatani padi. Adapun penggunaan tenaga kerja yang digunakan di lahan sawah baru dilihat dari dua musim. 
Tabel 9.

Penggunaan Tenaga Kerja Musim Tanam Pertama Sebelum dan Sesudah Adanya Program Pencetakan Sawah Baru di Desa Botto, Kecamatan Pitu Riase, Kabupaten Sidrap, 2018.

\begin{tabular}{llrrrr}
\hline \multirow{2}{*}{ No. } & Penggunaan Tenaga Kerja & \multicolumn{2}{c}{ Sebelum } & \multicolumn{2}{c}{ Sesudah } \\
\cline { 3 - 6 } & $\begin{array}{c}\text { Rata-Rata TK } \\
\text { (Orang) }\end{array}$ & $\begin{array}{c}\text { Rata-Rata } \\
\text { HOK/Ha }\end{array}$ & $\begin{array}{c}\text { Rata-Rata TK } \\
\text { (Orang) }\end{array}$ & $\begin{array}{c}\text { Rata-Rata } \\
\text { HOK/Ha }\end{array}$ \\
\hline 1 & Pengolahan Lahan & 0,00 & 0,00 & 1,00 & 2,59 \\
2 & Penanaman & 0,00 & 0,00 & 1,00 & 0,50 \\
3 & Pemeliharaan & 0,00 & 0,00 & 1,00 & 1,42 \\
4 & Pemupukan & 0,00 & 0,00 & 1,00 & 0,49 \\
5 & Penyemprotan & 0,00 & 0,00 & 1,00 & 0,40 \\
6 & Pengangkutan & 0,00 & 0,00 & 7,00 & 0,85 \\
7 & Pamanenan & 0,00 & 0,00 & 7,00 & 0,83 \\
\hline \multicolumn{2}{c}{ Jumlah } & $\mathbf{0 , 0 0}$ & $\mathbf{0 , 0 0}$ & $\mathbf{1 9 , 0 0}$ & $\mathbf{7 , 0 8}$ \\
\hline
\end{tabular}

Tabel 9 menunjukkan sesudah adanya program terdapat penggunaan tenaga kerja dibandingkan sebelum adanya program. Hal ini dikarenakan sebelum adanya program petani responden tidak melakukan aktivitas usahatani dilahannya.

Tabel 10.

Penggunaan Tenaga Kerja Musim Tanam Kedua Sebelum dan Sesudah Adanya Program Pencetakan Sawah Baru di Desa Botto, Kecamatan Pitu Riase, Kabupaten Sidrap, 2018.

\begin{tabular}{|c|c|c|c|c|c|}
\hline \multirow[b]{2}{*}{ No. } & \multirow[b]{2}{*}{ Penggunaan Tenaga Kerja } & \multicolumn{2}{|c|}{ Sebelum } & \multicolumn{2}{|c|}{ Sesudah } \\
\hline & & $\begin{array}{l}\text { Rata-Rata TK } \\
\text { (Orang) }\end{array}$ & $\begin{array}{c}\text { Rata-Rata } \\
\text { HOK/Ha }\end{array}$ & $\begin{array}{c}\text { Rata-Rata TK } \\
\text { (Orang) }\end{array}$ & $\begin{array}{c}\text { Rata-Rata } \\
\text { HOK/Ha }\end{array}$ \\
\hline 1 & Pengolahan Lahan & 0,00 & 0,00 & 1,00 & 3,75 \\
\hline 2 & Penanaman & 0,00 & 0,00 & 2,00 & 0,59 \\
\hline 3 & Pemeliharaan & 0,00 & 0,00 & 1,00 & 1,66 \\
\hline 4 & Pemupukan & 0,00 & 0,00 & 1,00 & 0,65 \\
\hline 5 & Penyemprotan & 0,00 & 0,00 & 1,00 & 0,51 \\
\hline 6 & Pengangkutan & 0,00 & 0,00 & 7,00 & 0,84 \\
\hline 7 & Pamanenan & 0,00 & 0,00 & 7,00 & 1,02 \\
\hline & Jumlah & 0,00 & 0,00 & 20,00 & 9,02 \\
\hline
\end{tabular}

Tabel 10 menunjukkan ada perbedaan penggunaan tenaga kerja sebelum dan sesudah adanya program. Dari Tabel terlihat jika tidak ada penggunaan tenaga kerja sebelum adanya program. Artinya dengan adanya lahan sawah baru hasil program pencetakan sawah baru secara tidak langsung memberikan peluang kerja baru bagi masyarakat.

b. Interaksi Sosial Petani

Interaksi sosial dapat dipahami sebagai hubungan-hubungan sosial yang terbangun secara dinamis antar individu, antar kelompok, maupun antara individu dan kelompok. Adapun bentuk interaksi petani di Desa Botto dapat dilihat pada Tabel 11. 
Tabel 11.

Interaksi Petani Sebelum dan sesudah Adanya Program Pencetakan Sawah Baru di Desa Botto, Kecamatan Pitu Riase, Kabupaten Sidrap, 2018.

\begin{tabular}{crrrr}
\hline Bertemu dan Berbicara Sesama Petani & \multicolumn{2}{c}{ Sebelum } & \multicolumn{2}{c}{ Sesudah } \\
\cline { 2 - 5 } (Kali/Musim Tanam) & orang & \multicolumn{1}{c}{$\%$} & Orang & \multicolumn{1}{c}{$\boldsymbol{0}$} \\
\hline$<5$ & 35 & 68,63 & 9 & 17,65 \\
$5-7$ & 16 & 31,37 & 31 & 60,78 \\
$>7$ & 0 & 0,00 & 11 & 21,57 \\
\hline Jumlah & $\mathbf{5 1}$ & $\mathbf{1 0 0 , 0 0}$ & $\mathbf{5 1}$ & $\mathbf{1 0 0 , 0 0}$ \\
\hline Lama Pembicaraan (Menit) & & & & \\
$<13$ & 25 & 49,02 & 17 & 33,33 \\
$13-16$ & 18 & 35,30 & 19 & 37,26 \\
$>16$ & 8 & 15,68 & 15 & 29,41 \\
\hline Jumlah & $\mathbf{5 1}$ & $\mathbf{1 0 0 , 0 0}$ & $\mathbf{5 1}$ & $\mathbf{1 0 0 , 0 0}$ \\
\hline Frekuensi Kehadiran pada Pertemuan & & & & \\
Kelompok Tani (Kali/Musim Tanam) & & & & \\
$<1$ & 0,00 & 0,00 & 0 & 0,00 \\
1-1.3 & 0,00 & 0,00 & 23 & 45,10 \\
$>1.3$ & 0,00 & 0,00 & 28 & 54,90 \\
\hline Jumlah & $\mathbf{0 , 0 0}$ & $\mathbf{0 , 0 0}$ & $\mathbf{5 1}$ & $\mathbf{1 0 0 , 0 0}$ \\
\hline
\end{tabular}

Tabel 11 menunjukkan terjadi peningkatan interaksi petani sesudah adanya program yang tergolong cukup sering dibandingkan sebelum adanya program. Artinya dengan adanya program intensitas pertemuan antar petani bertambah dan memiliki keinginan lebih untuk saling menyapa dan berinteraksi antar sesama petani.

Aspek Ekonomi

a. Mata Pencaharian Sebelum Adanya Program Pencetakan Sawah Baru

Mata pencaharian berarti pekerjaan yang menjadi pokok penghidupan (sumbu atau pokok), pekerjaan atau pencaharian utama yang dikerjakan untuk biaya seharihari (Sari, 2017). Jenis mata pencaharian petani responden sebelum dan sesudah adanya program pencetakan sawah baru dapat dilihat pada Tabel 12.

Tabel 12.

Mata Pencaharian Petani Responden Sebelum dan Sesudah Adanya Program Pencetakan Sawah Baru di Desa Botto, Kecamatan Pitu Riase, Kabupaten Sidrap, 2018.

\begin{tabular}{|c|c|c|c|c|c|}
\hline \multicolumn{6}{|c|}{ Mata Pencaharian Responden } \\
\hline \multirow{2}{*}{ No. } & \multirow{2}{*}{ Pokok } & \multicolumn{2}{|c|}{ Sebelum } & \multicolumn{2}{|c|}{ Sesudah } \\
\hline & & Orang & $(\%)$ & Orang & $(\%)$ \\
\hline 1 & Petani & 50 & 98,04 & 51 & 100,00 \\
\hline \multirow[t]{3}{*}{2} & Pedagang & 1 & 1,96 & 0 & 0,00 \\
\hline & Jumlah & 51 & 100,00 & 51 & 100,00 \\
\hline & Sampinga & & & & \\
\hline 1 & Pekebun & 3 & 75,00 & 3 & 100,00 \\
\hline \multirow[t]{2}{*}{2} & Tukang Batu & 1 & 25,00 & 0 & 0,00 \\
\hline & Jumlah & 4 & 100,00 & 3 & 100,00 \\
\hline
\end{tabular}


Tabel 12 terlihat bahwa sesudah adanya program tidak ada lagi petani responden yang bekerja sebagai pedagang. Artinya, dengan adanya program pencetakan sawah baru telah menyebabkan munculnya sumber mata pencaharian. Adapun status mata pencaharian sebelum dan sesudah adanya program dapat dilihat pada Tabel 13.

Tabel 13.

Status Mata Pencaharian Petani Responden Sebelum dan Sesudah Adanya Program Pencetakan Sawah Baru di Desa Botto, Kecamatan Pitu Riase, Kabupaten Sidrap, 2018.

\begin{tabular}{|c|c|c|c|c|c|}
\hline \multicolumn{6}{|c|}{ Status Mata Pencaharian Responden } \\
\hline \multirow{2}{*}{ No. } & \multirow{2}{*}{ Pokok } & \multicolumn{2}{|c|}{ Sebelum } & \multicolumn{2}{|c|}{ Sesudah } \\
\hline & & Orang & $(\%)$ & Orang & $(\%)$ \\
\hline 1 & Petani Pemilik Penggarap & 2 & 3.92 & 19 & 37.25 \\
\hline 2 & Petani Pemilik & 31 & 60.78 & 32 & 62.75 \\
\hline 3 & Petani penggarap & 17 & 33.33 & 0 & 0.00 \\
\hline 4 & Perantau & 1 & 1.97 & 0 & 0.00 \\
\hline \multicolumn{2}{|r|}{ Jumlah } & 51 & 100.00 & 51 & 100.00 \\
\hline \multicolumn{6}{|c|}{ Sampingan } \\
\hline 1 & Pemilik Kebun & 3 & 75.00 & 3 & 100.00 \\
\hline 2 & Buruh Tukang Batu & 1 & 25.00 & 0 & 0.00 \\
\hline \multicolumn{2}{|r|}{ Jumlah } & 4 & 100.00 & 3 & 100.00 \\
\hline
\end{tabular}

Sesudah adanya program pencetakan sawah baru, status mata pencarian beberapa petani yang sebelumnya tidak memiliki lahan sawah, dengan adanya program pencetakan sawah baru petani tersebut memiliki lahan sawah sendiri sehingga terjadi perubahan status mata pencaharian. Mata pencaharian seseorang seringkali berubah baik karena faktor internal, eksternal, ataupun kombinasi dari keduanya (Wahyu, 2007).

\section{b. Pendapatan}

Pendapatan merupakan selisih antara penerimaan dengan total biaya yang dikeluarkan selama proses produksi. Pendapatan dalam penelitian ini adalah pendapatan yang diperoleh di luar program dan pendapatan sesudah adanya program. Pendapatan yang diperoleh petani responden di luar program berasal dari lahan yang dimiliki petani responden sebelum adanya program. Total luas lahan petani responden di luar program seluas 61,40 Ha dengan rata-rata 1,20 Ha.

Tabel 14 menunjukkan bahwa proporsi pendapatan usahatani sebelum adanya program yaitu 61,59\% dan sesudah adanya program 75,24\% sedangkan proporsi pendapatan di luar usahatani sebelum adanya program yaitu 38,41\% dan sesudah adanya program $24,76 \%$. Terlihat ada peningkatan pendapatan sesudah adanya program. 
Tabel 14.

Rata-rata Pendapatan Petani Responden Sebelum dan Sesudah Adanya Program Pencetakan Sawah Baru di Desa Botto, Kecamatan Pitu Riase, Kabupaten Sidrap, 2018.

\begin{tabular}{|c|c|c|c|}
\hline \multirow[t]{2}{*}{ No. } & \multirow[t]{2}{*}{ Pendapatan Usahatani } & \multirow{2}{*}{$\begin{array}{c}\begin{array}{c}\text { Sebelum } \\
\text { Diluar program }\end{array} \\
\text { Nilai }(\mathbf{R p}) \\
\end{array}$} & \multirow{2}{*}{$\begin{array}{c}\text { Sesudah } \\
\text { Adanya program } \\
\text { Nilai }(\mathrm{Rp}) \\
\end{array}$} \\
\hline & & & \\
\hline 1 & Musim Tanam 1 & $28.574 .243,16$ & $36.679 .819,18$ \\
\hline 2 & Musim Tanam 2 & $28.647 .724,32$ & $38.117 .525,35$ \\
\hline & Jumlah & $57.221 .967,48$ & 74.797.344,53 \\
\hline \multicolumn{4}{|c|}{$\begin{array}{l}\text { Pendapatan Luar } \\
\text { Usahatani Padi }\end{array}$} \\
\hline 1 & Kebun & $12.936 .000,00$ & $24.614 .333,33$ \\
\hline 2 & Tukang Batu & $1.750 .000,00$ & - \\
\hline 3 & Pedagang & $21.000 .000,00$ & - \\
\hline & Jumlah & $35.686 .000,00$ & $24.614 .333,33$ \\
\hline & Total & 92.907.967,48 & 99.411.677,86 \\
\hline
\end{tabular}

\section{Kesimpulan}

1. Program pencetakan sawah baru di Desa Botto, Kecamatan Pitu Riase, Kabupaten Sidrap mengubah profil usahatani dalam hal luas lahan non produktif dan yang dimanfaatkan, fungsi dan pemanfaatan lahan, jenis tanaman yang dibudidayakan, status kepemilikan dan pajak lahan. Pemanfaatan sumber daya manusia, sumber daya peralatan, sumber daya finansial dan kondisi sarana penunjang.

2. Program pencetakan sawah baru memberikan perubahan sosial ekonomi kepada masyarakat di Desa Botto berupa penggunaan tenaga kerja, peningkatan interaksi sesama petani, perubahan status mata pencaharian dan peningkatan pendapatan.

\section{Daftar Pustaka}

Badan Pusat Statistik Kabupaten Sidenreng Rappang. 2017. Dalam Angka 2017.

Badan Pusat Statistik. 2016. Outlook Komoditi Pertanian Sub Sektor Tanaman Pangan. Kementerian Pertanian.

Kurniawan, Benny. 2017. Analisis Dampak Ekonomi Program Pencetakan Sawah Baru di Jorong I Siguhung Nagari Lubuk Basung Kecamatan Lubuk Basung Kabupaten Agam (Skripsi). Padang: Universitas Andalas.

Sari, Okki Kurnia. 2017. Perubahan Mata Pencaharian Suku Akit Di Desa Kembung Baru Kecamatan Bantan Kabupaten Bengkalis. Universitas Riau. Jurnal. Vol. 4 No. 2.

Sugiyono. 2008. Metode Penelitian Kuantitatif Kualitatif. Bandung: Alfaveta.

Wahyu, Supriyadi Waskito. 2007. Pergesaran Mata Pencaharian Masyarakat Desa (Skripsi). Surakarta: Universita Sebelas Maret. 